\title{
Allele-Specific Oligonucleotide Real-Time Quantitative Polymerase Chain Reaction
}

National Cancer Institute

\section{Source}

National Cancer Institute. Allele-Specific Oligonucleotide Real-Time Quantitative

Polymerase Chain Reaction. NCI Thesaurus. Code C116549.

An application of real time PCR that is capable of detecting and quantifying a specific

allelic version of a gene. 